\title{
Publisher Correction: The choice of biopolymer is crucial to trigger angiogenesis with vascular endothelial growth factor releasing coatings
}

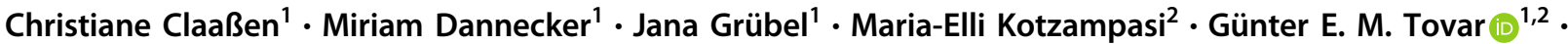 \\ Boris V. Stanzel $\mathbb{1}^{3,4,5} \cdot$ Kirsten Borchers ${ }^{1,2}$
}

Published online: 26 November 2020

(c) Springer Science+Business Media, LLC, part of Springer Nature 2020

Correction to: Journal of Materials Science: Materials in Medicine (2020) 31:93

https://doi.org/10.1007/s10856-020-06424-3

The original version of this article unfortunately contained few mistakes. The Orcid ID https://orcid.org/0000-00024316-1539 and third affiliation Department of Ophthalmology, University of Bonn, Ernst-Abbe-Str. 2, 53127 Bonn, Germany was missing for the co-author Boris V. Stanzl. The graphical abstract had a gray stain and Fig. S1 in Electronic Supplementary Material had error. The original article has been corrected.

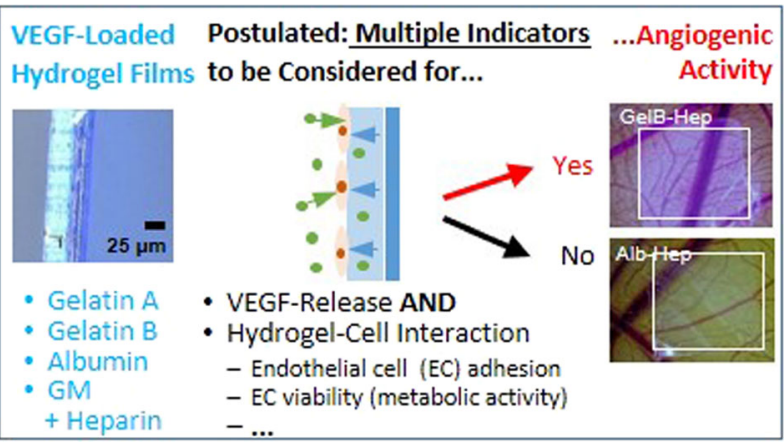

The original article can be found online at https://doi.org/10.1007/ s10856-020-06424-3.

\section{Günter E. M. Tovar}

guenter.tovar@igvp.uni-stuttgart.de

1 Institute of Interfacial Process Engineering and Plasma Technology IGVP, University of Stuttgart, Nobelstr. 12, 70569 Stuttgart, Germany

2 Fraunhofer Institute for Interfacial Engineering and Biotechnology IGB, Nobelstr. 12, 70569 Stuttgart, Germany
Augenklinik Sulzbach, Knappschaftsklinikum Saar, An der Klinik 10, 66280 Sulzbach, Germany

4 Fraunhofer Institute for Biomedical Engineering IBMT, Josephvon-Fraunhofer-Weg 1, 66280 Sulzbach/Saar, Germany

5 Department of Ophthalmology, University of Bonn, Ernst-AbbeStr. 2, 53127 Bonn, Germany 


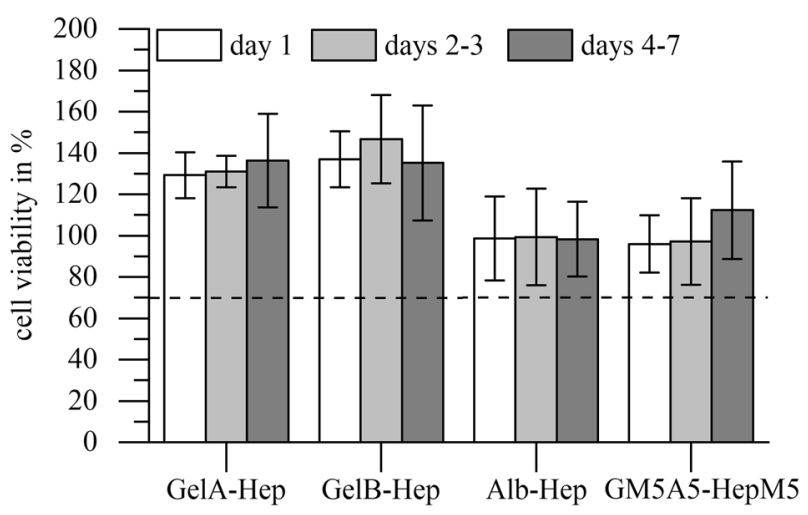

Fig. S1 Compatibility of hydrogel extracts in endothelial cell growth medium with endothelial cells. GelA-Hep and GelB-Hep extracts resulted in higher cell viabilities compared to the viability (100\%) of control cells cultured in standard endothelial cell growth medium (100 $\%, p<0.05$ ), while Alb-Hep and GM5A5-HepM5 extracts showed similar viabilities to the control $(p>0.1) .(n=3)$ 